\title{
My Path in Hyperthermia Research and Expectations for the Future
}

\author{
MITSUYUKI ABE \\ Professor Emeritus, Kyoto University, 6-3 Yoshidakaguraoka-cho, Sakyo-ku, Kyoto 606-8311, Japan
}

\begin{abstract}
The purpose of this paper is to review a history of hyperthermia research in Japan focusing on the fields in which I have been engaged.

Hyperthermia research in Japan was started in 1975 when T. Sugahara, Professor of Kyoto University organized a hyperthermia research group supported by a Grant-in-Aid for Cancer Research from the Ministry of Education, Science and Culture. T. Sugahara and M. Abe developed an $8 \mathrm{MHz}$ RF capacitive heating device in cooperation with Yamamoto Vinyter Co. in 1983. This machine named Thermotron-RF8 was first officially recognized as a heating device for cancer therapy by the Ministry of Health and Welfare in 1984. Thereafter a variety of machines have been developed for clinical use and the rapid expansion of activity in hyperthermia research in various fields including radiation biology and physics led to the foundation of the Japanese Society for Hyperthermic Oncology in 1984. From the latter of 1980 to the first half of 1990 hyperthermia has gained a significant degree of popularity. However since clinical hyperthermia today is a time- and man power- consuming procedure, done with still immature machines and is an inexact treatment method, enthusiasm has gradually been reduced. In order to revitalize clinical hyperthermia it is absolutely important to develop a heating device that can heat tumors in various locations selectively and homogeneously to desired temperatures and to obtain thermal mapping and monitor the temperature non-invasively during each treatment session. We must also define "thermal dose" in terms which are clinically relevant to the biological effect. It is my hope that hyperthermia will be established as one of the standard methods for cancer therapy by resolving the problems stated above in the future.
\end{abstract}

Key Words : history, hyperthermia, oncology

始めに

本稿は 2013 年 8 月 30-31 日, 横浜で開催された第 30 回日本ハイパーサーミア学会学術大会で行っ た記念講演の内容を纏めたものである.

Received 22 October, 2013, Accepted 4 November, 2013. *Corresponding author; Tel, +81-75-761-3864; Fax, +81-75-761-3864; e-mail, m-abe@ kyoto.zaq.ne.jp

doi : 10.3191/thermalmed.29.69

(C) 2013 Japanese Society for Thermal Medicine 


\section{日本におけるハイパーサーミア研究の幕開け}

日本における本格的なハイパーサーミア研究は，1975 年に当時京都大学医学部放射能基礎医学教室 の教授であった菅原努先生が文部省科学研究費がん特別研究 1「制がんにおける放射線作用の修飾とそ の意義」という班を組織し，その研究テーマの一つとしてハイパーサーミアを取り上げたことに始まる といえよう.

私は班員として菅原班に参加し，ハイパーサーミアの臨床研究を開始した。その理由は当時の放射線 治療には二つの大きな問題があると思っていたからである.すなわち，物理学的な問題としては放射線 の腫瘍に対する線量分布の局在性が悪いこと, 生物学的な問題としては放射線の殺細胞効果が十分でな いということである．そのため当時の放射線治療は副作用が大きく，しかも放射線単独では制御できな い腫瘍が少なからず存在したのである。私は前者の問題に対しては手術により腫瘍を可及的に切除し， 遺残病巣に対して手術中に直接照射する「術中照射法」1)により解決しようとした. 後者に対しては放射 線増感剤とハイパーサーミアによって突破口を開きたいと考えたのである. 残念ながら放射線増感剤は 私の教室でも長年研究を続けたが，満足すべき薬剤を開発するには至らなかった。一方ハイパーサーミ アは 1970 年代に入ってから欧米で急速に基礎研究が進み, 熱をがん治療に利用する科学的根拠が次久 と報告されたため，私は本格的にハイパーサーミアの臨床研究に取り組むことにした.

\section{がんに対するハイパーサーミア療法の歴史的背景}

ハイパーサーミア療法の歴史は紀元前にさかのぼることができる.下肢に生じた腫瘍を焼き鏝 (コテ) で燒灼している甚だ乱暴なギリシャ時代の絵があることから，既にこの時代から熱をがん治療に使用し ていたと推測されるからである。近代的な意味で熱に制がん効果があることを最初に示したのはドイツ の医師 W. Busch ${ }^{2}$ であろう。彼は 1866 年，顔に生じた肉腫が丹毒による 2 回の発熱で消失した症例を 報告した. 続いて 1893 年アメリカの医師 W.B. Coley ${ }^{3)}$ が細菌毒素をがんの周辺に注射して炎症を起こ させ，その熱で治療を試みている。しかし，熱の生物学的作用が培養細胞や実験動物を使って正確に分 析され，その効果が定量的に示されるようになったのはようやく 1970 年代になってからである. その なかで私が特に重要と考えた実験データを以下に列挙する.

1）培養液を $41^{\circ} \mathrm{C}$ 以上に加温すると加温時間とともに細胞の生存率が低下するが，特に $42.5^{\circ} \mathrm{C}$ 上上の 加温で顕著に低下する4).

2）細胞周期に依存して, 放射線と熱に対する細胞の感受性が異なる. 即ち $\mathrm{S}$ 期の細胞は放射線に最 も感受性が低く抵抗性であるが，熱に対しては最も感受性が高い5)。したがって放射線と熱との併 用により相乗効果が期待できる.

3）培養液の $\mathrm{pH}$ を低下させると細胞の温度感受性が増加する ${ }^{6}$. 腫瘍には低酸素状態の細胞群があり, それが放射線や抗がん剂に対して抵抗性であることはよく知られている。方，低酸素細胞は正常 細胞より $\mathrm{pH}$ が低いので, 熱に対しては弱いと考えられる.したがって放射線治療や抗がん剤と熱 の併用により，それぞれ単独で行うより優れた制がん効果が期待できる.

4）アドリアマイシンやブレオマイシンの殺細胞効果が $43^{\circ} \mathrm{C} の$ 加温により著明に増強されることが チャイニーズハムスター細胞を使った培養系の実験で示された7).

5）同様の実験系で $\mathrm{X}$ 線による細胞生存率が $42^{\circ} \mathrm{C}$ 以上の加温で著しく低下することが明らかにされ $た^{8)}$.

6）正常組織は血管分布が良好なので，血流による冷却効果があるのに対して，腫瘍は一般に血流が悪

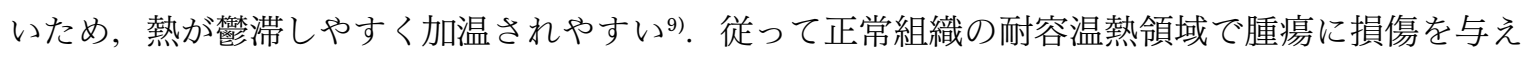


うると考えられる.

\section{加温装置開発の経緯}

上に述べたようにハイパーサーミアにはがん治療に適用できる明確な基礎的根拠があることから，当 時私どもの教室にあった $2,450 \mathrm{MHz}$ の理学療法用へリカルアンテナ型マイクロ波加温装置を使って, 放射線治療単独では治癒困難と考元られた局所進行性の乳癌や煩粘膜癌などの表在性難治癌を対象に八 イパーサーミア併用放射線治療を試みた。その結果，予想以上の局所制御効果が得られたので，本格的 な加温装置を開発すべく 1977 年菅原努先生と共に某電機メーカーに加温装置の開発を頼みに上京した が，人体の局所加温は技術的に困難と言われ断られた．私は人間が月世界に行ける時代になったのに何 故だという思いであった．しかし後に，この技術開発が如何に困難なものかを思い知ることになった.

失望して京都に帰って間もなく, 大阪の工業用高周波専門メーカー山本ビニター社の山本五郎専務が 上記某電機メーカーの紹介で菅原教授室を訪ね, 共同開発を申し出たのである.その席に私も呼ばれ, 本格的に装置の開発に着手することになった，開発を始めると人体の場合は加温に対して血流の増加に より恒温状態を保とうとする強力な生理機能を発揮するため, 任意の部位を局所的に目的の温度に加温 することは非常に困難であった，試行錯誤を繰り返し，ようやく 1979 年 $13.56 \mathrm{MHz}$ 誘電加温装置を開 発した (Fig. 1). しかしこの装置は深部腫場に対しては十分な加温が困難であったため, 1982 年, 新技術 開発事業団から研究費を受けて改良を重水，1984 年，Fig. 2 に示す加温装置を開発し Thermotron-RF8 と名付けた。この装置は日本で初めてがん温熱療法用加温装置として薬事審議会で承認され, 厚生省の 製造承認を取得して全国に販売された.

苦労の末に開発した加温装置が薬事審議会で認められた時，私はふと湯川秀樹先生の言葉を思い浮か べた．この会場には若い研究者が多数扔られるので, 何かの参考になればと思い紹介したい.

私は大学院時代, 湯川先生の素粒子論の講義を聴講していた，ある日先生は講義の中で, “自分は年 をとったせいか，大きな仕事ができなくなってきた．年と共に知識は増えるのに何故できないのかを考 えると，色々な知識があると先が見通せるようになる，そのため，こちらの道はけわしくなる，あちら の道は行き詰まるだろう, といった具合に先が読めるので, つい無難な道を選ぶことになる. しかし無 難な道は決して大きな成果をもたらさない. 自分の若い頃を振り返ると, 今より知識は少なかった. そ のためかえって，今から思えば大きすぎるような目標を立て，それに向かってひたすら研究を続け，そ れが新しい発見につながった”という趣旨の話をされたことがある，この時，私は大事なのは「知識よ

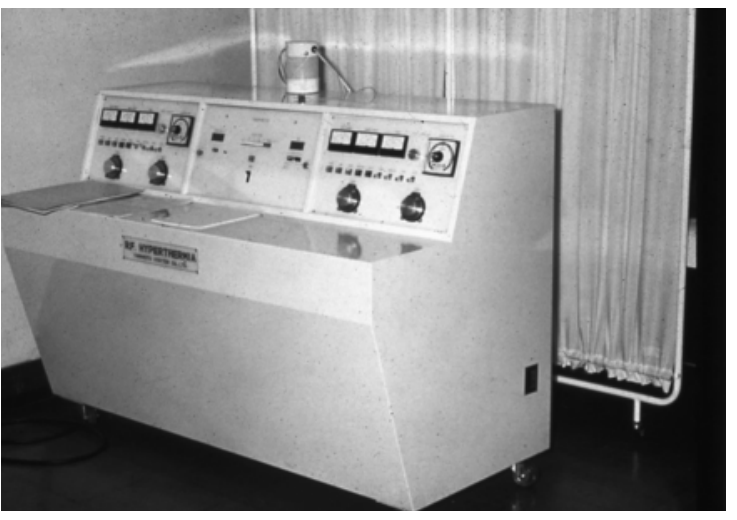

Fig. 1. 山本ビニター株式会社と 1979 年に共同開発 した $13.56 \mathrm{MHz}$ RF 加温装置第 1 号機

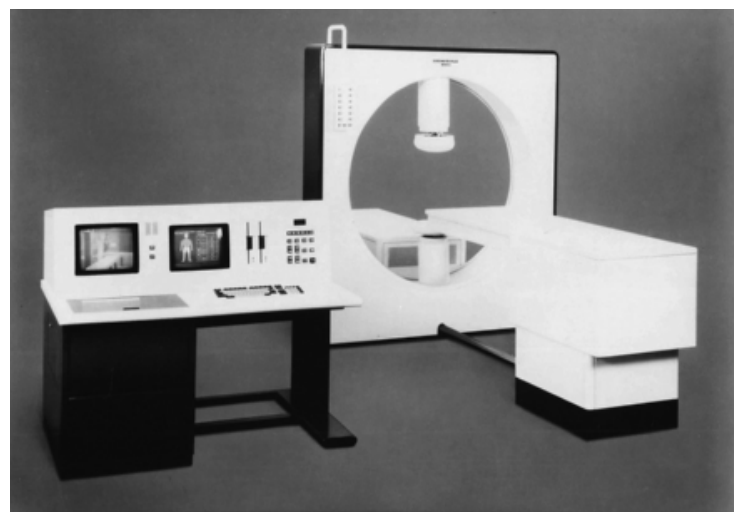

Fig. 2. 1984 年加温装置として日本で最初に厚生省の 製造承認を取得した Thermotron-RF-8. 
Thermal Med, 29 [4] : 69-78, 2013.

り意志」ということではないかと思った，先生の発見とは比較にならないが，山本専務は “自分はプラ スチックや木材を加温する技術と経験を持っている．だから人間を加温する装置も作れると思う”と言 う。私は月世界に行ける時代にできないはずはないと思っていた．しかし私共は加温に対して人体が反 応する温熱生理の強力なメカニズムを深く考えていなかった，教室員たちも皆若く，黙々と加温装置の 開発に取り組んだ。かくして先の読めない者同士が集まって夢中で突き進んだことが加温装置の開発を 可能にした，と今にして思うのである.

1985 年, がんのハイパーサーミア療法が NHK 午後 9 時の News Center (NC9) に取り上げられ, 私が この番組に呼ばれて話をしたところ, 国内のみならず国外からも問い合わせの電話が殺到し，その対応 に追われて 1 週間ほど本来の仕事ができなかったため, マスコミの威力に驚いたことを記憶している.

\section{ハイパーサーミア研究会の設立}

次に日本に抢けるハイパーサーミアの研究会, 学会の設立とその歩みについて述べる. 八イパーサー ミアは物理・工学, 生物学, 医学に跨る学際的な分野であることから, 1978 年, 菅原努先生が各分野の専 門家から成るハイパーサーミ ア研究会を設立した。その第 1 回研究会は参加者約 50 人, 演題数 17 題という小規模な ものであった．当時のハイ パーサーミア研究の状況がど のようなものであったかを示 すため, 発表演題の内訳を Table I に要約する. Table I に示すごとく, 当時は熱の発 生に関する物理・工学的研究 と培養細胞と動物を使っての

Table I. 1978 年 10 月 7 日大阪で開催された第 1 回ハイパーサーミア研究会の発表 演題の要約

\begin{tabular}{ll}
\hline 発表演題数 17 題 (参加者約 50 名) \\
\hline • 電磁波, 超音波による温熱発生に関するもの & 3 題 \\
・ 培養細胞に対する温熱効果に関するもの & 9 題 \\
- 動物に対する温熱効果に関するもの & 3 題 \\
- 臨床研究 & 2 題 \\
1) 膀胱癌の Hyperthermia 療法: & \\
Bleomycin および放射線との併用療法について & 横浜市大 西村 隆一 \\
2) 膀胱癌の放射線, 温熱併用療法の経験 & 川崎医大 小野山靖人 \\
\hline
\end{tabular}
温熱効果の生物学的研究がほとんどを占め, 臨床研究は 2 題に過ぎなかった. 面白いことに 2 題とも膀 胱癌に対する温熱併用放射線抢よび抗がん剂治療に関する研究であった。いずれも加温方法は膀胱内に 温水を潅流することによるもので，まだ加温装置が開発されていなかった時代のハイパーサーミア療法 として興味深い.

この研究会は年々参加者が増加し, 研究発表も盛んになり, 1983 年東京で行われた第 6 回研究会で は参加者が約 360 名, 演題数は招待講演, シンポジウムを含めて 124 題となった. 一般演題の内容は加 温の理論と技術に関するものが 27 題, 温度計測 16 題, 生物実験 28 題, 血流に関する演題 7 題, 臨床 応用が 33 題で, 生物, 物理・工学領域の基礎研究のみならず, 臨床応用に関する演題も急増した. これ が契機となりハイパーサーミア研究の更なる発展を目指して, この第 6 回研究会の折, 研究会を発展的 に解散して学会を設立することが決議された。

\section{日本ハイパーサーミア学会の設立}

決議に基づき, 1984 年菅原努先生を会長に, 私が準備委員長を務め第 1 回日本ハイパーサーミア学 会の学術大会を京都で開催した.この時の参加者は約 650 人, 一般演題は 144 題となり, ハイパーサー ミア研究は大きく発展した. この大会を総括して私がハイパーサーミア療法の今後の研究課題として掲 
げたテーマを Table II に示す.

Table II. 1984 年第 1 回日本ハイパーサーミア学会学術大会を総括して示したがんハイパー サーミア療法の今後の研究課題

\begin{tabular}{l}
\hline 物理・工学領域 \\
1. 任意の部位の腫瘍を必要な温度に加温できるハイパーサーミア治療装置の開発 \\
2. 非侵襲的温度測定技術の開発 \\
\hline 生物学領域 \\
1. 熱の生物効果を推定できるような単位 (Thermal dose) の検討 \\
2. Thermal tolerance の解明 \\
\hline 臨床医学領域 \\
1. 放射線治療あるいは抗がん剤とハイパーサーミアとの至適組み合わせの研究 \\
2. ハイパーサーミア療法の効果判定基準の確立 \\
\hline
\end{tabular}

1984 年, 後に述べるデンマークの J. Overgaard が第 4 回国際ハイパーサーミア研究会をオーフスで 開催した時, 第 5 回を日本で開催してくれるよう要請されたので, 1988 年菅原努先生が会長, 私が事 務総長を務め, 第 5 回日本ハイパーサーミア学会を第 5 回国際ハイパーサーミアシンポジウムとの共催 で京都にて開催した.この時の参加者は国内外合わせて 845 人に達し, 特別講演 13 題, 一般演題 381 題という盛大な会となった。

今回の学術大会は日本ハイパーサーミア学会の母体となったハイパーサーミア研究会が設立されてか ら 35 年, 学会となってからは丁度 30 年となる節目の記念すべき大会である. しかも横浜市立大学は先 に述べた如く, 1978 年第 1 回ハイパーサーミア研究会に扔いて同大学病院泌尿器科の西村隆一先生が 膀胱癌に対するハイパーサーミア療法を発表したことから, 日本で最も早くハイパーサーミアの臨床研 究をスタートさせた大学の一つといえる，その意味で今回，藤内祝教授が第 30 回大会を主催されたこ とは大変意義深いことである．この学術大会で同教授が掲げた「ハイパーサーミア 30 年の歩みと未来」 というメインテーマのもと, 学会参加者は 257 人, 特別企画, 一般講演など 114 題が発表されること は，ハイパーサーミア研究に関する最新の情報を知り，そして将来を予測する上で大変重要な大会にな る.

\section{海外におけるハイパーサーミア研究会，学会の設立}

一方, 海外に抒けるハイパーサーミア研究の推移を見ると, 1975 年 J.E. Robinson と M.J. Wizenberg によって第 1 回国際ハイパーサーミアシンポジウムがワシントンD.C. で開催されたが，こ の時の参加者は約 70 人という小さな会で, 日本からは参加していない. 第 2 回は C. Streffer が 1977 年 ドイツのエッセンで開き, 参加者約 200 人で, この内日本からは 5 名出席している. 第 3 回は W.C. Deweyにより 1980 年コロラド州フォートコリンズで開催され, 参加者約 460 人中日本からは 11 人が 出席し, 私もその一員として初めて参加した. またコロンビア大学の E. Hall が “Biology is with us but physics is against us” という有名な言葉を述べたのがこの時である.これは，八イパーサーミアは生物 学的に有効性が示されているが，それを臨床に移行できる加温装置の開発は困難であることを的確に表 現したものだが，残念ながら今日なおこの言葉は生きている. 第 4 回は上に述べた J. Overgaard が開催 し, 参加者約 600 人, その内日本からは 45 人が参加した. こうしたハイパーサーミア研究の目覚まし 
Thermal Med, $29\lceil 4]:$ 69-78, 2013.

い発展により，1992 年には国際ハイパーサーミア学会 (ISHO) が，更に 1996 年にはアジアハイパー サーミア学会 (ASHO) が創設された.

振り返って私は 1990 年前後が世界的にハイパーサーミア研究の最も活気に溢れた時代ではなかった かと思う. 国内外のハイパーサーミアに関する研究会, 学会の設立の年代と参加人数の変遷を Table III に要約する.

Table III. 国内外のハイパーサーミアに関するシンポジウム, 研究会, 学会の設立, 開催時期, 参加者数

\begin{tabular}{|c|c|c|c|c|}
\hline 年 & シンポジウム, 研究会, 学会 & $\begin{array}{l}\text { 参加人数 } \\
\text { (日本人) }\end{array}$ & 国内研究会・学会 & 参加人数 \\
\hline 1975 & 第 1 回国際シンポ (ワシントン) & $70(0)$ & & \\
\hline 1977 & 第 2 回国際シンポ (エッセン) & $200(5)$ & & \\
\hline 1978 & ハイパーサーミア研究会設立 & & 第 1 回研究会 (大阪) & 50 \\
\hline 1979 & & & 第 2 回研究会 (大阪) & 76 \\
\hline 1980 & 第 3 回国際シンポ (コロラド) & $460(11)$ & 第 3 回研究会 (京都) & 150 \\
\hline 1981 & 米国ハイパーサーミアグループ (NAHG) 設立 & & 第 4 回研究会 (東京) & 219 \\
\hline 1982 & & & 第 5 回研究会 (名古屋) & 254 \\
\hline 1983 & ヨーロッパハイパーサーミア学会 $(\mathrm{ESHO})$ 設立 & & 第 6 回研究会 (東京) & 360 \\
\hline 1984 & $\begin{array}{l}\text { 日本ハイパーサーミア学会 (JSHO) 設立 } \\
\text { 第 } 4 \text { 回国際シンポ (オーフス) }\end{array}$ & $600(45)$ & 第 1 回学会 (京都) & 650 \\
\hline 1986 & & & 第 3 回学会 (大阪) & 750 \\
\hline 1987 & & & 第 4 回学会 (米子) & 500 \\
\hline 1988 & 第 5 回国際シンポ (京都) & $845(375)$ & $\begin{array}{l}\text { 第 } 5 \text { 回学会 (京都) } \\
\text { 国際シンポと共催 }\end{array}$ & \\
\hline 1992 & $\begin{array}{l}\text { 第 } 6 \text { 回国際シンポ (ツーソン) } \\
\text { 国際ハイパーサーミア学会 (ISHO) 設立 }\end{array}$ & $636(141)$ & 第 9 回学会 (金沢) & 400 \\
\hline 1996 & アジアハイパーサーミア学会 (ASHO) 設立 & & & \\
\hline 2013 & & & 第 30 回学会 (横浜) & 257 \\
\hline
\end{tabular}




\section{健康保険採用までの経緯}

ハイパーサーミア療法の目覚 ましい普及により，学会では 1986 年から健保採用に向けて 活動が開始された。 4 年後の 1990 年にようやく放射線治療 との併用でハイパーサーミア療 法の健保採用が認められ, 更に 1996 年には単独でも認められ た (Table IV). これはハイパー サーミア療法ががん治療法の一 つとして正式に認知されたこと を意味するもので，学会会員の喜びは非常に大きかった。

\section{日本におけるハイパーサーミア研究の推移}

1970 年代から始まった日本のハイパーサーミア研究が年と共にどのように変化して行ったかを要約 して Table V に示す。初期は放射線や抗がん剂を併用した膀胱癌に対する温水潅流療法 ${ }^{10)}$ が試みられ たが，1980 年代に入るとがんの再発，転移症例に対して抗がん剤と体外循環装置を用いた血液加温に よる全身ハイパーサーミア療法 ${ }^{11)}$ が行われるようになった. 1980 年の中頃に加温装置が開発され臨床 に使われるようになってからは放射線, 抗がん剤併用局所ハイパーサーミア療法淿が主流となり， 種々の加温装置を使って臨床成績が報告された. Heat shock protein ${ }^{13)}$ の生物学的研究が始まったのは この頃である. 同年後半には強磁性体微粒子による選択的ハイパーサーミア療法 ${ }^{14,15)}$ や針インプラント

Table V. 日本におけるハイパーサーミア研究の推移

\begin{tabular}{|c|c|c|}
\hline \multicolumn{2}{|c|}{ 年 代 } & 研 究 の 推 移 \\
\hline \multirow[t]{2}{*}{$\begin{array}{l}1970 \text { 年代 } \\
1980 \text { 年代 }\end{array}$} & $\begin{array}{l}\text { 後半 } \\
\text { 前半 }\end{array}$ & $\begin{array}{l}\text { 膀胱癌に対する放射線，抗がん剂併用温水潅流療法 } \\
\text { 体外循環装置を用いた血液加温に抗がん剂を併用した全身ハイパーサーミア療法 } \\
\text { 各種加温装置を用いた放射線併用ハイパーサーミア療法 } \\
\text { Heat shock proteinの生物学的研究 }\end{array}$ \\
\hline & 後半 & $\begin{array}{l}\text { 強磁性体微粒子による選択的ハイパーサーミア療法 } \\
\text { 針インプラントによる低周波誘導ハイパーサーミア療法 } \\
\text { マイクロ波による組織内加温 } \\
\text { NMR による非侵襲体内温度計測法 }\end{array}$ \\
\hline \multirow[t]{2}{*}{1990 年代 } & 前半 & レーザーハイパーサーミア療法 (脳腫瘍, 前立腺癌に適用) \\
\hline & 後半 & $\begin{array}{l}\text { インピーダンス CT による非侵襲生体内温度分布測定法 } \\
\text { プロトン磁気共鳴による非侵襲温度分布画像化 } \\
\text { マイクロ波 CT による非侵襲生体内温度分布測定法 }\end{array}$ \\
\hline \multirow[t]{2}{*}{2000 年代 } & 前半 & $\begin{array}{l}\text { ラジオ波焼灼療法 (主に肝癌に適用) } \\
\mathrm{RF} \text { 組織内加温 (主に脳腫瘍に適用) }\end{array}$ \\
\hline & 後半 & 磁性ナノ粒子を用いた細胞内加温 \\
\hline 2010 年代 & 前半 & $\begin{array}{l}\text { 強力集束超音波 (HIFU) を用いたハイパーサーミア療法 } \\
\text { 低強度超音波と微小気泡の併用によるハイパーサーミア療法 }\end{array}$ \\
\hline
\end{tabular}


Thermal Med, $29\lceil 4]:$ 69-78, 2013.

による低周波誘導加温 ${ }^{16,17)}$ ，マイクロ波を使った組織内加温 ${ }^{18)}$ が行われるようになった。また NMR を使っての非侵襲体内温度計測法 $\left.{ }^{19}\right)$ が提案され, 八イパーサーミア療法にとって必須の体内温度測定 を非侵襲的に行う研究として注目された。

引き続き 1990 年代も非侵襲体内温度計測法の研究が盛んになり, インピーダンス CT による非侵襲 生体内温度分布測定法 ${ }^{20)}$ やプロトン磁気共鳴による非侵襲温度分布の画像化 ${ }^{21)}$ ， マイクロ波 CT によ る非侵襲生体内温度分布測定法 ${ }^{22)}$ などが次々と発表された。しかしいずれも未だ実用化されておらず, ハイパーサーミア療法の進歩に欠くことのできない重要研究テーマとして残されている. 臨床面では 1990 年代前半にレーザーによる脳腫瘍 ${ }^{23)}$ や前立腺癌 ${ }^{24)}$ の治療が行われた.

2000 年代になると, ラジオ波焼灼療法 ${ }^{25,26)}$ や $\mathrm{RF}$ 組織内加温 ${ }^{27)}$ が肝癌や脳腫瘍に適用され, 後半に は磁性ナノ粒子を用いた細胞内加温 ${ }^{28)}$ の研究が行われるようになった.

更に 2010 年代になると強力集束超音波 (HIFU) や低強度超音波と微小気泡の併用によるハイパー サーミア療法 ${ }^{29}$ の 研究が発表されるなど, 加温装置を使った従来の治療法の外に, RF 波, 超音波など を用いた組織内加温が盛んに行われるようになり，ハイパーサーミア療法は著しく多様化してきた.

\section{ハイパーサーミア療法の今後の課題}

ハイパーサーミア療法の今後の研究課題として私が重要と思われるものを Table VI に示す．これを 1984 年第 1 回学会の時に掲げた研究課題と比較すれば明らかなように, 物理・工学領域および生物学領 域においては内容が殆ど同じである，ということは 30 年経過してなおこれら重要課題は解決されてい ないということである. 今後のハイパーサーミア療法の発展のためには何といっても任意の部位の腫瘍 をできるだけ限局性に目的とする温度に加温できる高精度加温装置の開発と, その腫瘍内の温度分布を 非侵襲的に測定し，これを 3 次元的に画像化して表示する技術開発が何より重要である.

次にハイパーサーミアの生物学的効果を推定できるような単位, 即ち Thermal dose をどう決めるか 検討する必要がある. 温度は積算できる量ではなく, 生物学的にも物理学的にも複雑な問題があるので 容易ではないが，単位がなければ治療計画や治療法の研究，治療効果の分析や，異なるハイパーサーミ ア療法間の比較など定量的に研究することができず，真の科学にはなりえないからである.

医学領域の課題として重要なのは, 抗がん剤, 免疫療法の治療効果を高めるためのマイルドハイパー サーミアの研究である. 何故なら局在性のがんは今日, 高精度放射線治療や外科手術の進歩により制御 率が著しく向上したが，全身的ながんは依然として余り改善されていないからである．従って今後は転 移や多発がんを如何に制御するかが重要かつ契緊の課題になる。この問題に対しては抗がん剂に頼る外 はないが，現在その効果は限定的である，八イパーサーミアを併用すれば，抗がん剂の作用が増強され

Table VI. 今後のハイパーサーミア研究の重要課題

物理・工学領域

1. 任意の部位の腫瘍をできるだけ限局性に加温できる高精度加温装置の開発

2. 非侵襲性 3 次元温度分布測定法の開発とその画像化

物理・生物学領域

1. 熱の生物効果を推定できる単位 (Thermal Dose) の確立

臨床医学領域

1. 抗がん剂, 免疫療法の治療効果の向上を目指したマイルドハイパーサーミア療法の研究

2. 腫瘍組織あるいは腫瘍細胞特異的ハイパーサーミア療法の研究 
ることが多くの臨床成績で示され，その際必ずしも $42^{\circ} \mathrm{C}$ 以上の高温を必要としないことも報告されて いる．従って転移がん患者の治療成績の改善に，マイルドハイパーサーミアと抗がん剤の至適な組み合 わせに関する基礎的，臨床的研究が重要である。

一方, 最近のハイパーサーミア療法の方向をみると, がん組織特異的に集積するナノバブルと低強度 集束超音波との併用により局所的に高温を発生させてがんを破壞するハイパーサーミア療法29)や正常 細胞と悪性細胞との電気的特性の違いを利用して, 腫瘍細胞を選択的に攻撃するオンコサーミアの研 究年) が行われつつある. こうした従来のマクロ的ハイパーサーミアからミクロ的ハイパーサーミアに 向かう研究が今後どのように発展するのか注目される.

\section{終わりに}

熱をがん治療に利用する理論的根拠が 1970 年代から 80 年代に多くの生物学的基礎研究によって与え られたことから，八イパーサーミア療法はがんに対する治療法，あるいは放射線や抗がん夙の効果を高 める補助療法として世界的に注目され，各国で盛んに行われるようになった。しかし人体内の病巣を限 局性に一定の温度に加温できる精度と信頼性の高い装置が開発されないことから，1990 年以降，次第 にハイパーサーミア療法は以前の勢いを失いつつある。私は長年放射線治療に従事してきたが，かつて は放射線治療装置が未成熟で病巣を限局性に照射できなかった，従って腫瘍制御効果は低く, 副作用が 大きいという問題のため，1990 年の放射線治療新患数は全国で約 63,000 人に過ぎなかった. しかし強 度変調放射線治療や粒子線治療といった高精度の放射線治療装置が開発されたことにより放射線治療の 信頼性が高まり，2010 年には約 216,000 人と 20 年間で 3.4 倍に増加した．このことを考えれば，ハイ パーサーミア療法の未来は既に述べた如く如何に優れた加温装置を開発するかに掛かっていると言って も過言ではないであろう. 従ってこれからハイパーサーミア研究に携わる医用工学の研究者と医師が医 用機器メーカーと一体になって, 新しい高精度加温装置と非侵襲的温度測定装置を開発すること, そし て学会がそれを後押しすることが何より重要である.

上に述べた課題を解決することにより，ハイパーサーミア療法ががん治療の一翼を担う一つの柱とし て確立されることを心から願うものである.

\section{参考文献}

1) Abe M., Fukuda M., Yamano K., Matsuda S., Handa H.: Intra-operative irradiation in abdominal and cerebral tumours. Acta Radiol, 10: 408-416, 1971.

2) Busch W.: Ueber den Einfluss welche heftigere Erysipeln zuweilig auf organisierte Neubildungen aus ueben. Vrh Naturhist, Preuss Rhein Westphal, 23 : 28-30, 1866.

3) Coley W.B.: The treatment of malignant tumors by repeated inoculations erysipelas with a report of ten original cases. Am J Med Sci, 105 : 487-511, 1893.

4) Dewey W.C., Hopwood L.E., Sapareto L.A., Gerweck L.E. : Cellular responses to combinations of hyperthermia and radiation. Radiology, 123 : 463-474, 1979.

5) Gerweck L.E., Gillette E.L., Dewey W.C. : Effect of heat and radiation on synchronous Chinese hamster cells : killing and repair. Radiat Res, 64: 611-623, 1975.

6) Gerweck L.E.: Modification of cell lethality at elevated temperatures. The pH effect. Radiat Res, 70: 224-235, 1977.

7) Hahn G.M., Braun J., Har-Keder I.: Thermochemotherapy: Synergism between hyperthermia $\left(42-43^{\circ} \mathrm{C}\right)$ and adriamycin or bleomycin in mammalian cell inactivation. Proc Natl Acad Sci USA, 72: 937-940, 1975.

8) Ben-Hur E., Elkind M.M., Bronck B.V.: Thermally enhanced response of cultured Chinese hamster cells : inhibition 
Thermal Med, 29 [4] : 69-78, 2013.

of repair of sublethal damage and enhancement of lethal damage. Radiat Res, 58: 38-51, 1974.

9) Song W.C.: Effect of local hyperthermia on blood flow and microenvironment: A review. Cancer Res, 44 : 4721-4730, 1984.

10）岡田清己，清滝修二，川添和久，佐藤安男，田原亮一，木下正之，熊谷振作，北島清彰，尾上泰彦，滝本至得， 岸本孝：膀胱腫瘍に対する温水療法の研究. 第 2 報 日泌尿会誌, 68：128-135, 1977.

11) Koga S., Izumi A., Maeta M., Shimizu N., Osaki Y., Kanayama H.: The effects of total-body hyperthermia combined with anticancer drugs on immunity in advanced cancer patients. Cancer, 52: 1173-1177, 1983.

12) Abe M., Hiraoka M. : Localized hyperthermia and radiation in cancer therapy, Review. Int J Radiat Biol, 47 : 347-359, 1985.

13) Yamamori T., Yura T.: Genetic control of heat-shock protein synthesis and its bearing on growth and thermal resistsnce in Escherichia coli k-12. Proc Natl Acad Sci USA, 79: 860-864, 1982.

14）山口哲, 馬場正博, 鈴木恵史, 久代裕史, 福島元彦, 村上雅彦, 新井一成, 小池正：リポゾーム性強磁性体微粒子 の作製と高周波磁場照射による加温. Jpn J Hyperthermic Oncol, 2：407-412, 1986.

15）佐古正雄, 広田省三, 大梘修平, 清水雅史, 田中浩司, 村上徹, 阿曽一雄, 河野道雄: 磁性粒子を標的とした誘導 加温による選択的深部加温の研究. Jpn J Hyperthermic Oncol, 2 : 389-394, 1986.

16）木村一路，大坪研成，香月武，後藤昌昭：口腔癌温熱療法のための針インプラントによるVLF 誘導加熱法. Jpn J Hyperthermic Oncol, 3 : 155-163, 1987.

17）藤内祝，後藤康之，林康司，金田敏郎，小林達也，木田義久，松井正顕：舌癌に対する Implant Heating System に よる組織内温熱療法. Jpn J Hyperthermic Oncol, 6：450-461, 1990.

18）鎌田正，高邑明夫，辻井博彦，斉藤博哉，松岡祥介，辻比呂志，入江五朗，佐藤隆文： $915 \mathrm{MHz}$ マイクロ波を用い た組織内加温の試み. Jpn J Hyperthermic Oncol, 4 : 247-252, 1988.

19）水品静夫，浜村良紀，杉浦敏文：無侵襲体内温度計測. Jpn J Hyperthermic Oncol, 2：63-77, 1986.

20）酒本勝之, 沢田安彦, 藤井麻子, 金井寬：インピーダンス CT による体内温度変化分布の計測. Jpn J Hyperthermic Oncol, $12: 378-392,1996$.

21）黒田輝：プロトン磁気共鳴による非侵襲温度分布画像化：現状と展望. Jpn J Hyperthermic Oncol, 12：129-139, 1996.

22) Miyakawa M. : Recent progress in noninvasive thermometry. Jpn J Hyperthermic Oncol, 14 : 225-233, 1998.

23）垰本勝司, 伊地智昭浩, 巽祥太郎, 野添正彦, 仲里正孝, 在園則雄: Balloon probeを用いた術中 YAG laser hyperthermia による悪性脳腫瘍の治療. Jpn J Hyperthermic Oncol, 10：110-120, 1994.

24）鈴木孝憲，黒川公平，鈴木和浩，山中英寿：前立腺疾患に対する経尿道的バルーンレーザー治療の基礎的検討．Jpn J Hyperthermic Oncol, 10 : 121-125, 1994.

25) Izumi Y., Turuta K., Shibayama T., Hayashi S., Takahashi T. : Laparoscopic and thracoscopic radiofrequency ablation therapy for small hepatocellular carcinoma. Jpn J Hyperthermic Oncol, 18 : 151-156, 2002.

26) Otsuka T., Takagi H., Kanda D., Nakajima H., Mori M. : Radiofrequency ablation for primary and metastatic liver tumors : Indications and therapeutic effects. Jpn J Hyperthermic Oncol, 18 : 3-11, 2002.

27) Takahashi H., Tanaka R., Uzuka T., Kon T., Aoki H., Endo S., Kano M., Igor G. : Successful treatments of malignant glioma in the elderly by radiofrequency interstitial hyperthermia : A report of two cases. Jpn J Hyperthermic Oncol, 18 : 157-164, 2002.

28) Ito A., Kobayashi $\mathrm{T}$ : Intracellular hyperthermia using magnetic nanoparticles: A novel method for hyperthermia clinical applications. Thermal Med, 24 : 113-129, 2008.

29) Suzuki R., Oda Y., Omata D., Sawaguchi Y., Seki M., Uruga H., Naoi T., Negishi Y., Maruyama K. : Novel strategies for ultrasound diagnostics and therapeutics by micro/nanobubbles. Thermal Med, 29: 37-46, 2013.

30) Szasz A. : Challenges and solutions in oncological hyperthermia. Thermal Med, 29: 1-23, 2013. 